Published in final edited form as:

Cancer Epidemiol Biomarkers Prev. 2012 August ; 21(8): 1244-1259. doi:

10.1158/1055-9965.EPI-12-0485.

\title{
The Role of Obesity in Cancer Survival and Recurrence
}

\author{
Wendy Demark-Wahnefried ${ }^{1}$, Elizabeth A. Platz ${ }^{2}$, Jennifer A. Ligibel ${ }^{3}$, Cindy K. Blair ${ }^{1}$, Kerry \\ S. Courneya ${ }^{4}$, Jeffrey A. Meyerhardt ${ }^{3}$, Patricia A. Ganz ${ }^{5}$, Cheryl L. Rock ${ }^{6}$, Kathryn H. \\ Schmitz ${ }^{7}$, Thomas Wadden ${ }^{8}$, Errol J. Philip ${ }^{9}$, Bruce Wolfe ${ }^{10}$, Susan M. Gapstur ${ }^{11}$, Rachel \\ Ballard-Barbash ${ }^{12}$, Anne McTiernan ${ }^{13}$, Lori Minasian ${ }^{14}$, Linda Nebeling ${ }^{15}$, and Pamela J. \\ Goodwin \\ 1Department of Nutrition Sciences, University of Alabama at Birmingham, Birmingham, AL \\ ${ }^{2}$ Department of Epidemiology, Johns Hopkins Bloomberg School of Public Health, Baltimore, MD \\ ${ }^{3}$ Dana-Farber Cancer Institute, Harvard Medical School, Boston, MA \\ ${ }^{4}$ Faculty of Physical Education and Recreation, University of Alberta, Edmonton, Canada \\ ${ }^{5}$ Schools of Medicine and Public Health, University of California-Los Angeles, Los Angeles, CA \\ ${ }^{6}$ Department of Family and Preventive Medicine, University of California, San Diego, La Jolla, CA \\ ${ }^{7}$ Department of Biostatistics and Epidemiology, University of Pennsylvania, Philadelphia, PA \\ ${ }^{8}$ Center for Weight and Eating Disorders, University of Pennsylvania, Philadelphia, PA \\ ${ }^{9}$ Dept of Psychiatry \& Behavioral Sciences, Memorial Sloan-Kettering Cancer Ctr, New York, NY \\ ${ }^{10}$ Department of Surgery, Oregon Health and Science University, Portland, OR \\ ${ }^{11}$ Epidemiology Research Program, American Cancer Society, Atlanta, GA \\ ${ }^{12}$ Applied Research Program, National Cancer Institute (NCl), Bethesda, MD \\ ${ }^{13}$ Fred Hutchinson Cancer Research Center, Seattle, WA \\ ${ }^{14}$ Community Oncology and Prevention Trials Research Group, NCl, Bethesda, MD \\ ${ }^{15}$ Behavioral Research Program, NCl, Bethesda, MD \\ ${ }^{16}$ Dept. of Medicine, Mount Sinai Hospital, University of Toronto, Toronto, Ontario, Canada
}

\section{Abstract}

Obesity and components of energy imbalance, i.e., excessive energy intake and suboptimal levels of physical activity, are established risk factors for cancer incidence. Accumulating evidence suggests that these factors also may be important after the diagnosis of cancer and influence the course of disease, as well as overall health, well-being, and survival. Lifestyle and medical interventions that effectively modify these factors could potentially be harnessed as a means of cancer control. However, for such interventions to be maximally effective and sustainable, broad sweeping scientific discoveries ranging from molecular and cellular advances, to developments in delivering interventions on both individual and societal levels are needed. This review summarizes key discussion topics that were addressed in a recent Institute of Medicine Workshop entitled, "The Role of Obesity in Cancer Survival and Recurrence"; discussions included: 1) mechanisms associated with obesity and energy balance that influence cancer progression; 2) complexities of

Correspondence: Wendy Demark-Wahnefried, PhD, RD, 1675 University Blvd, Room 346, Birmingham, AL 35294-3360, Phone: 205.975.4022/FAX: 205.975.2592/demark@uab.edu.

There are no potential conflicts of interest. 
studying and interpreting energy balance in relation to cancer recurrence and survival; 3) associations between obesity and cancer risk, recurrence, and mortality; 4) interventions that promote weight loss, increased physical activity, and negative energy balance as a means of cancer control; and 5) future directions.

\section{Keywords}

neoplasms; obesity; diet; physical activity; survival; recurrence

\section{Introduction}

The hazards of obesity were first noted by the ancient Greeks. Hippocrates (460-370 BC), the "Father of Medicine" and the first to characterize the crab-like structure of cancer which he termed "karkinos," warned of the dangers of too much food and too little exercise (1). Almost two millennia later, Robert Thomas chronicled the link between obesity and endometrial cancer (2). Discoveries over the past century have significantly improved our understanding of the interrelationships between overweight/obesity, energy balance and cancer risk, as well as cancer recurrence and survival (2). Consensus now exists that obesity is a risk factor for cancers of the endometrium, colorectum, kidney, esophagus, breast (postmenopause), and pancreas, and evidence continues to mount regarding associations with cancers of the thyroid, gallbladder, liver, ovary and aggressive forms of prostate cancer, as well as non-Hodgkin lymphoma $(3,4)$. Moreover, obesity is increasingly recognized as a poor prognostic factor for several common malignancies (5-8). The effects of obesity on cancer incidence and poor outcomes in patients with cancer are especially worrisome in light of the obesity epidemic (9). Worldwide, estimates indicate that 1.5 billion adults are overweight (body mass index [BMI]:25-29.9 kg/m ${ }^{2}$ ) and 500 million are obese (BMI $\geq 30 \mathrm{~kg}$ / $\mathrm{m}^{2}$ ) (10). Also, with the earlier onset of overweight and obesity often occurring during childhood, there is considerable concern, since the life-time effects of obesity on cancer outcomes are yet unknown.

In a recent workshop convened by the Institute of Medicine's (IOM) National Cancer Policy Forum (October 31-Nov 1, 2011), experts in the fields of cancer survivorship and obesity met to discuss converging trends and the research gaps that exist (11). Discussions included: 1) mechanisms associated with obesity and energy balance that influence cancer progression; 2) complexities of studying and interpreting energy balance in relation to cancer recurrence and survival; 3) associations between obesity and cancer risk, recurrence, and mortality; 4) interventions that promote weight loss and negative energy balance as a means of cancer control; and 5) future directions. A review of these topics is reported herein.

\section{Energy Balance}

Historically, cancer has been a disease associated with cachexia (hypermetabolic state marked by anorexia and profound wasting), a problem that remains today for more advanced cancers (12). However, with more cancers diagnosed at earlier stages when cure is possible, and with the discovery that more cancers are being initiated or promoted by obesity (especially against the backdrop of the obesity epidemic), it is positive- rather than negativeenergy balance that appears to be the more prevalent problem.

Obesity results from chronic energy intake in excess of expenditures. Figure 1 illustrates the complex dynamic nature of energy balance in which intake (defined as absorbable energy, measured in kilocalories) is gauged against the energy demands of the body. Energy expenditure is comprised of three components: 1) resting metabolic rate (RMR), the energy required for normal body processes, which accounts for the majority of energy needs; 2 ) 
thermic effect of food, the relatively minor amount of energy needed to digest and metabolize food; and 3) physical activity, a moderate, but readily modifiable, constituent of energy expenditure. Theoretically, body weight shifts with every calorie of imbalance, with a total positive imbalance of 3,500 kcal promoting (or resulting in) a 1-pound increase in body weight. This simplistic model ignores differences in body composition (i.e., body stores of lean tissue, adipose tissue, stored glycogen and body water), and the dynamic state of body composition in which increases in lean mass occur as one exercises (especially resistance training) or decreases as with sarcopenia resulting from cancer treatments, such as chemotherapy (13). This is important since lean body mass determines RMR. This relationship is worth noting since it is unknown whether obesity per se drives cancer progression, or whether components of energy balance (i.e., too much energy consumed or too little energy expended) have a greater impact, and which factors hold promise for cancer control.

\section{Potential mechanisms by which positive energy balance contributes to cancer progression}

All of the putative mechanisms whereby obesity drives the progression of cancer are not yet known; however the process is acknowledged as complex. Earlier work focused on associations between obesity and higher levels of free circulating sex hormones (e.g., estradiol) and their impact on hormonally-linked cancers (14-17), such as cancer of the breast. Now a multitude of other mechanisms are being elucidated. Preclinical data indicate that energy balance may affect genomic instability, dysregulated growth signaling and cellular energetics, inhibition of apoptosis and immune surveillance, and angiogenesis (18). Moreover, myriad factors interact in an intricate signaling network to accelerate neoplasia. Data now exist for several factors including energy-driven signaling via insulin, insulin-like growth factor-1 (IGF-1) (crosstalk with epidermal growth factor), phosphatidylinositol 3kinase, and AMP-activated protein kinase, and many other entities. Components of insulin resistance syndrome (IRS) have been well-studied in both breast (19-23) and colorectal cancer (24-31). For example, in non-diabetic breast cancer patients, higher levels of fasting insulin have been associated with a 2- to 3-fold increased risk of mortality (19-23, 32). Overexpression of insulin receptors, notably the fetal insulin receptor (IRa) on breast cancer cells, provides a biologic basis for this effect, since expression of total insulin receptor or phosphorylated IGF-1 receptor/insulin receptor are associated with poorer breast cancer outcomes (33). Parallel findings are reported for colorectal cancer and suggest that physical activity, adiposity and diet influence insulin and IGF levels, which subsequently stimulate growth and inhibit apoptosis of micrometastases - a presumed cause of recurrence (34).

Moreover, adipose tissue, once thought to be inert, is now recognized as metabolically active and a source of inflammatory modulators. The adipokine, leptin, enhances the production of inflammatory factors, such as interleukin-6 (IL6), IL1 $\beta$, and tumor necrosis factor-a (TNFa) that lead to the activation of nuclear factor-kappa B (NFkB) and downstream effects that signal through the mammalian target of rapamycin (mTOR) to initiate transcription. This cascade also appears influenced by sex hormones (estradiol and testosterone) and growth factors, notably vascular endothelial growth factor (VEGF). In contrast, increased adiposity is associated with lower levels of adiponectin, an adipokine that induces apoptosis. Evidence for these mechanisms has been noted specifically in breast and colorectal cancer $(35,36)$. More detail on the mechanisms by which obesity drives cancer progression, as well as considerations and potential models to best study the relationship between energy balance and cancer are covered in another report emanating from this IOM Workshop (see Cancer Prevention XX:XXX-XXX, 2012). 


\section{Association between energy balance (body weight, energy restriction and increased physical activity) and cancer recurrence and survival \\ Preclinical Studies}

Given the difficulty in accurately assessing energy intake and energy expenditure in humans, fewer studies have addressed the individual components of energy balance in relation to cancer progression. However, there is substantive research in animal models. The first reported study of energy restriction was conducted in rodents by Moreschi in 1909 (37). In a transplanted tumor model, energy restriction was found to significantly reduce tumor growth as compared to an ad libitum control. Over the past century, similar experiments in a variety of animal models and using chemically-induced carcinogenesis, as well as transplanted tumors and/or cells, have produced profoundly consistent results: energy restriction inhibits neoplastic progression $(38,39)$. However, body weight is lower in the energy-restricted animals, and it is not possible to disentangle whether it is energy restriction or reduced adiposity that decreases tumor burden. Nor is it clear whether less extreme energy restriction or that which is instituted in obese animals after the onset of cancer would have similar effects - both of which have greater clinical relevance.

Animal studies of physical activity are more uncommon and have yielded inconsistent findings, with most studies addressing carcinogenesis rather than cancer progression. In the few studies of transplanted tumors or cell lines, two (in breast and pancreatic cancer) showed inhibition of tumor growth with increased physical activity $(40,41)$, one (in breast cancer) showed no difference (42), and one (in colon cancer) reported harm (43). Control of energy intake $(40,41)$, versus ad libitum feeding $(42,43)$, may have contributed to discrepant findings. Though not in a cancer model, Padovani et al. (44) attempted to disentangle energy balance factors by directly comparing the effects of energy restriction to increased energy expenditure on gene expression. Their 6-week study in C57B/6 mice showed that mammary gland gene expression profiles of mice assigned to increased physical activity versus controls varied with regard to 45 genes; in contrast, the mice assigned to energy restriction varied by 425 genes, with an overlap seen in only three genes. Thus, at least in animal models, the biological pathways affected by energy restriction appear quite different than those associated with energy expenditure, and the net effect of energy balance and obesity are likely to even further complicate these associations.

\section{Observational Studies}

Direct measures of body composition, such as dual energy X-ray absorptiometry and computed tomography (CT) are costly and cumbersome, thus most human studies of obesity and prognosis have used weight or BMI with an assumption that excess adipose tissue comprises much of the added mass. Waist circumference (a measure of central adiposity) also is frequently assessed to improve precision of the classification of obesity, but also to be able to evaluate whether the location of excess adiposity differently influences outcomes. In the growing body of survivorship research, data suggest that increasing BMI portends less favorable outcomes, not only with respect to cancer-specific recurrence and survival (stated above), but also for comorbidity (e.g., diabetes, cardiovascular disease, and poorer postsurgical wound healing and infection) and overall survival $(45,46)$. As with all cancerrelated research, controlling for cancer stage, grade, and treatment are of paramount importance; however, since weight loss can be a symptom of recurrent cancer, it is also important to distinguish whether changes in weight are volitional versus involuntary. A review of evidence from observational studies in breast, prostate and colorectal cancer follows. 
In a recent meta-analysis of over 40 studies of women diagnosed with breast cancer, Protani et al. (7) reported a modest, but statistically significant and clinically-relevant increase in allcause and breast cancer specific mortality in obese versus non-obese women (HR[95\% CI]): $1.33[1.21-1.47]$ and 1.33[1.19-1.50], respectively) regardless of whether obesity was characterized by BMI or waist:hip ratio, whether the study was observational or a trial of therapy, whether patients were premenopausal, postmenopausal or both, and whether the study was published prior to 1995 or after (when anthracycline/taxane-based adjuvant therapies were more commonly used). Moreover, emerging evidence suggests the adverse effects of obesity on breast cancer outcomes persist long-term $(6,35)$. Obesity has been consistently associated with prostate cancer mortality in cohort studies of men without the disease at baseline (47-49). Recent studies suggest that obesity around the time of diagnosis and afterwards, as well as weight gain are associated with poorer outcomes among men diagnosed with the disease (5); these findings are independent of the higher incidence of advanced stage and high Gleason sum disease seen in obese compared with nonobese men. For colorectal cancer, data have only recently emerged and suggest mixed results. Most studies of adiposity and outcomes in non-metastatic colorectal cancer show poorer outcomes solely in extremely obese patients, i.e., BMI $\geq 35 \mathrm{~kg} / \mathrm{m}^{2}(8,50-55)$. In a cohort of $\sim 4,000$ stage II-III colon cancer patients participating in four NCI-sponsored adjuvant therapy trials, BMI $\geq 35 \mathrm{~kg} / \mathrm{m}^{2}$ was associated with a $38 \%$ increased risk of recurrence and a $36 \%$ increased risk of disease-specific mortality (53). Two studies have assessed change in weight postdiagnosis or post-diagnosis BMI on cancer recurrence and survival and neither found an association $(51,56)$, with the more recent study by Campbell et al. suggesting that obesity pre-diagnosis is most important.

To date, no observational studies assessed energy intake using validated methods, though several have evaluated associations between dietary factors and cancer outcomes, especially in breast $(57,58)$, colon (59), and prostate cancers (60-62). However, few consistent relationships have emerged for intakes of specific micro- or macro-nutrients, or dietary patterns.

Several reports suggest that physical activity after cancer diagnosis is associated with better cancer-specific and overall survival in individuals diagnosed with early-stage breast, prostate, and colorectal cancers (63-67). Seven prospective cohort studies, including almost 20,000 individuals in aggregate, examined the relationship between physical activity after breast cancer diagnosis and recurrence and disease-specific mortality $(63,68-73)$. Six of the seven studies suggest that women who participate in modest levels of physical activity postdiagnosis have significantly better outcomes as compared to sedentary women. For example, women who engage in $>9$ MET-hours/week of physical activity (equivalent to walking at an average pace for 3 hours/week) had a 50\% lower risk of breast cancer death, and all-cause mortality, than women who were inactive (engaging in $<1$ hour of moderateintensity activity/week) (63). Similar findings have been reported in colorectal cancer survivors, in whom participation in $\geq 18$ MET-hours/week of post-diagnosis physical activity was associated with a $50 \%$ lower risk of cancer recurrence and/or mortality $(64,65,74)$. For prostate cancer, a $46 \%$ reduction in overall mortality was observed among prostate cancer survivors who walked for $\searrow 90$ minutes/week and reductions of $61 \%$ and $49 \%$ were seen respectively in prostate-specific and all-cause mortality in men who engaged in $\geq 3$ hours/ week of vigorous activity (66). Despite this observational evidence, the impact of increasing physical activity after cancer diagnosis upon prognosis has yet to be tested in randomized trials. However, small interventional studies in breast cancer survivors have shown that physical activity leads to improvements in serum insulin and other biomarkers linked to breast cancer risk and prognosis $(75,76)$. Further research is needed to understand the impact of physical activity on cancer outcomes, especially since observational studies are unable to discern cause and effect, and exercise clusters with many other health behaviors, 
including healthier diets and treatment adherence (77). The Colon $\underline{\text { Health }} \underline{\text { and }}$ LifeLong Exercise Change (CHALLENGE) trial is one such trial and will be described in a subsequent section.

In summary, obesity, excessive energy intake, and physical inactivity may be important modifiable risk factors for poor cancer outcomes. However, a few critical limitations of the extant research should be acknowledged. Notably, few studies have complete data on specific cancer treatment regimens. With early studies demonstrating that obese breast cancer patients receive less adequate doses of chemotherapeutic agents, treatment stands as an important confounder or effect modifier (78). While new guidelines have led to improved dosing among obese patients, the uptake of these recommendations is inconsistent, especially across community-based practices. Practice patterns also are influenced by the presence of co-morbidities, which are highly prevalent among cancer patients since cancer is a disease of aging. An example that well illustrates this complex situation is provided by diabetes mellitus, an obesity-related comorbid disease that reportedly occurs in 5-17\% of individuals with breast, colon or prostate cancer (79). Here, the risk of death may be 2 to 3 fold higher compared to mortality in cancer patients without co-occurring diseases (79), with previous studies purporting that this may be attributed either to less aggressive cancer treatment among diabetics (80), or to less aggressive glucose control among those diagnosed with cancer (81). Moreover, few studies have controlled for medication-use, despite emerging evidence that some agents, e.g., metformin or insulin, may have direct effects on cancer outcomes (82). Thus, much more research is needed to resolve the many knowledge gaps that remain at the interface of energy balance and cancer (Table 1). Consideration of several methodological and inferential issues is key in moving the science forward most expeditiously (Table 2).

\section{Weight loss, diet, and physical activity interventions}

\section{Lessons learned from weight loss interventions in the general population}

During the past 40 years, the prevalence of obesity among US adults has more than doubled -from $15 \%$ to $35 \%(9,83)$. The increased risk of chronic disease morbidity and mortality resulting from obesity has prompted efforts to develop effective weight loss interventions for the general population. The lessons learned from these interventions provide a backdrop for their translation to cancer survivors. Interventions that have been broadly tested in the general population include lifestyle modification, pharmacotherapy, and bariatric surgery.

A comprehensive program of lifestyle modification, which includes diet, exercise, and behavior therapy, is the most broadly recommended approach for weight loss (84). The goal of this approach is a reduction in body weight of at least $7-10 \%$, which has been shown to improve several obesity-related conditions, such as diabetes mellitus and risk of cardiovascular disease (CVD) (84). The US Preventive Services Task Force recommends that clinicians screen all adults for obesity and offer intensive (at least monthly) counseling and behavioral interventions to promote sustained weight loss $(85,86)$. Numerous randomized controlled trials have concluded that achieving an energy deficit of 500-1000 $\mathrm{kcal} /$ day (sufficient to induce a 1-2 pound/week loss) is a central component of any weight loss regimen, and that varying the macronutrient content is not as important as overall energy intake (87-89); though for cancer survivors, eating a diet that is nutritionally sound and which meets cancer prevention guidelines is advised $(3,90)$. Long-term patient-provider contact and high levels of physical activity (200-300 minutes/week of brisk walking) are necessary to maintain lost weight $(89,91,92)$. The Diabetes Prevention Program (DPP) (93) and the Look AHEAD study $(94,95)$ are two of the largest lifestyle modification weight loss trials. The DPP randomized 3234 obese adults with impaired glucose tolerance to usual care, metformin, or a lifestyle intervention. Lifestyle intervention participants were instructed to 
(i) reduce their energy intake by $500-1000 \mathrm{kcal} /$ day (by decreasing portion sizes, fat, and sugar), (ii) increase fruit and vegetable intake, and (iii) exercise for $>150$ minutes/week (96). They kept records of their weight, food intake, and physical activity, which they reviewed regularly with dietitians. The study demonstrated that a mean loss of $7 \%$ of initial weight reduced the risk of developing type 2 diabetes by $58 \%$ compared with placebo and by $31 \%$ compared with metformin (over an average follow-up of 2.8 years). The Look AHEAD study is now testing whether a $7 \%$ or greater weight loss in overweight/obese adults with type 2 diabetes will reduce cardiovascular morbidity and mortality over a 13.5-year followup $(94,95)$. In the first year, lifestyle participants lost $8.6 \%$ of their initial weight and achieved substantial improvements in fitness and CVD risk factors, compared with usual care. Four-year weight losses were $4.7 \%$ and $1.1 \%$, in intervention and control groups respectively (97). Further follow-up is needed to determine whether improvements in CVD risk factors in the lifestyle group translate into reduced morbidity and mortality.

Pharmacotherapy is an option for individuals with a BMI $>30 \mathrm{~kg} / \mathrm{m}^{2}$ (or $>27 \mathrm{~kg} / \mathrm{m}^{2}$ with comorbid conditions) (84). At present, orlistat is the only weight loss medication approved for long-term use (98). It produces losses that are $3 \mathrm{~kg}$ greater than placebo $(99,100)$. The largest weight losses are obtained when pharmacotherapy is combined with lifestyle modification $(101,102)$. For those severely obese, bariatric surgery (including verticalbanded gastroplasty, gastric bypass, and laparoscopic adjustable gastric banding) offers the most assured approach to weight loss as assessed by both short- and long-term outcomes $(101,103,104)$. Weight loss at 1 - to 2 -years may be as high as $32 \%$ of initial weight. At 10years, weight loss averages 14-26\%, depending on type of surgery (101). Enthusiasm for this success is tempered, in part, by limits to the proportion of the population for whom surgery is recommended, i.e., $5.1 \%$ of the U.S. population with a BMI $>40 \mathrm{~kg} / \mathrm{m}^{2}(84,105)$, as well as attendant risks, e.g., mortality rates of $0.1-0.3 \%$ and complication rates of $4-9 \%$ $(106,107)$. Of particular interest in the context of this review, a diagnosis of cancer within the past five years has generally been a contraindication to bariatric surgery. Longitudinal data in obese populations however shows that weight loss accomplished by surgery reduces cancer incidence and mortality compared to people who have not undergone bariatric surgery. Most of these studies reported risk estimates for cancer incidence rather than cancer mortality. The numbers of women enrolled in these studies of bariatric surgery are much larger than the numbers of men, which may be one reason that statistically significant associations with cancer incidence and mortality have been observed predominantly for women (108). The one study that reported hazard ratios for the effect of bariatric surgery on cancer mortality observed a 50\% reduction in cancer mortality for women (103). All of these studies have been based on obese patients, very few of whom had any prior history of cancer and none were undergoing active treatment for cancer. Whether the effects of bariatic surgery on cancer mortality are due entirely to a reduction in cancer incidence, or whether it confers additional survival benefit post-diagnosis are yet to be determined $(101,109)$. This raises the intriguing concept that weight loss may be beneficial in contributing to short- and long-term survival in cancer patients.

\section{Issues and challenges for interventions that target cancer survivors}

The promotion of weight loss and lifestyle change in cancer survivorship can present several challenges unique to this growing population. Side effects and post-treatment symptomatology are common and can interfere with patients' abilities to engage in a weight loss intervention and their consequent success. For example, weight loss may have to be postponed until primary treatment is complete in order to assure adequate immune function; moreover, risks for infection in gym-based programs must be considered (110). Another consideration is chemotherapy-induced sarcopenia which can be exacerbated by rapid weight loss (exceeding 2 pounds/week) via regimens that are focused solely on diet (13) - 
thus reinforcing the need for multi-component interventions that incorporate exercise (especially resistance training). Fatigue and changes in appetite and taste sensation are often reported by survivors, while body image concerns may be prompted or exacerbated by the impact of treatment (111-114). However, in several cancer patient groups, studies have demonstrated that patients who continue or engage in physical activity following diagnosis experience less fatigue (115). Furthermore, some evidence suggests that engaging in physical activity may reduce the likelihood of experiencing adverse treatment side effects and increase compliance with therapy (115). Disease, treatment or patient characteristics may necessitate appropriate screening and adaptations of exercise involvement to assure that fractures, musculo-skeletal injuries and cardiac risk are minimized (115). Additionally, some patients will experience psychological distress (116), e.g., symptoms of depression and anxiety, which can impair motivation and engagement in a lifestyle-based intervention. Importantly, individuals diagnosed and treated for cancer who succeed in losing weight may find that intentional weight loss is perceived by some individuals as indicative of disease recurrence or progression and a cause for concern. Although weight management and lifestyle change are recommended in overweight and obese survivors, the impact of weight loss on disease outcomes has not been demonstrated. However, given the documentation of the common occurrence of obesity-related comorbid disease among many cancer survivors and the increased risk of death in these patients, it is hypothesized that weight loss in overweight and obese survivors would be beneficial.

\section{Prior energy balance interventions in cancer survivors}

\section{Accrual, retention, adherence, and scope of research}

To date, most diet and physical activity interventions have been conducted in well-educated, non-Hispanic white, breast cancer survivors. Survivor accrual into energy balance interventions requires considerable time and effort, and achieving high retention and adherence is challenging, underscoring the importance of detailed reporting of characteristics of respondents versus non-respondents, completers versus drop-outs, and participants with high versus low adherence (117). The ability of intervention trials to successfully recruit and retain a representative sample of cancer survivors, with minimal attrition and high adherence rates, is essential for the eventual translation and dissemination of effective interventions more broadly, including underrepresented subgroups, such as lower socio-economic status, rural, and racial-ethnic minority survivors.

\section{Physical activity interventions in cancer survivors}

Few physical activity trials have focused on survival, because of the extended duration of study and sample sizes required, or on weight loss, presumably because of the modest effects of physical activity alone on weight loss in other populations (118). However, physical activity trials have demonstrated improvements in many health outcomes in cancer survivors including health-related fitness (119), fatigue (120), depression (121), and quality of life (122). Moreover, there is emerging evidence that stronger effects accrue for physical activity interventions that are supervised $(121,122)$, facility-based (121), at least of moderate intensity $(120,122), \geq 30$ minutes/session (121), and delivered after completion of primary curative treatment (119).

Based on the strong observational data on the benefits of physical activity after a colorectal cancer diagnosis, a multinational trial in Canada and Australia, the CHALLENGE trial, was developed. The goal of the trial is to determine the effects of a 3-year structured and supervised physical activity intervention on disease outcomes in 962 high-risk stage II-III colon cancer survivors who have completed adjuvant chemotherapy within the previous 2-6 months (123). The primary endpoint is disease-free survival and secondary endpoints 
include patient-reported outcomes, health-related fitness, biologic correlative markers, and an economic analysis. The trial is currently open to accrual and incorporates intervention approaches shown effective. Like most other trials of physical activity, CHALLENGE is not aimed at weight loss, but body weight status will be monitored and explored in relation to disease outcomes.

\section{Diet and weight loss interventions in cancer survivors}

The Women's Intervention Nutrition Study (WINS) (124) and the Women's Healthy Eating and Lifestyle (WHEL) (125) trials, conducted among early stage breast cancer survivors, tested the effects of dietary interventions on cancer recurrence and survival, although neither was directly aimed at energy restriction. The WINS intervention $(n=2437$, enrolled within one year of diagnosis), promoted a low-fat diet to only $15 \%$ of energy intake through individualized dietary counseling provided by registered dietitians (124). Self-reported fat intake approximated $20 \%$ of energy intake in the intervention group versus $29 \%$ of intake in the control group at 12 months. At 5 years, women assigned to the low-fat intervention lost an average of 6 pounds ( $4 \%$ of initial weight) compared to controls. There were significantly lower rates of recurrence observed in the intervention arm overall (HR:0.76; 95\% CI:0.60-0.98), and particularly among women with estrogen receptor negative disease (HR:0.58; 95\%CI:0.37-0.91). In contrast, the WHEL intervention ( $n=3088$, enrolled up to 4 years post diagnosis), used telephone-based dietary counseling to promote a daily intake of five vegetable servings plus 16 ounces of vegetable juice or equivalent, three fruit servings, $30 \mathrm{~g}$ fiber, and $15-20 \%$ energy from fat (125). Participants randomized to the dietary intervention significantly increased intake of fruit and vegetables, and decreased intake of fat, with no differences observed in weight change between arms. After a median follow-up of 7.3 years and 518 relapse events, there were no between-arm differences in recurrence $(16.7 \%$ versus $16.9 \%)$ or survival $(10.1 \%$ versus $10.3 \%)$. While the high fruit and vegetable intake of WHEL participants at baseline may have undermined the trial's ability to detect between-arm differences, the differential in weight change observed between the two trials also may have contributed to the discrepant findings.

Similar to WINS, other dietary interventions resulted in modest (2-3\% of initial body weight) yet significant weight loss as a consequence of lower fat, high fruit and vegetable diets, e.g., the FRESH START trial conducted in 543 newly-diagnosed breast and prostate cancer survivors (126). Additionally, weight gain prevention interventions have also been evaluated during adjuvant chemotherapy for breast cancer, when weight gain is common (127-129). However to date, only six diet or diet and exercise intervention trials have pursued weight loss as a specific aim (130-135).

Earlier studies relied on individual dietary counseling to deliver guidance on energyrestriction (130), while more recently group-based support has been used to bolster individualized approaches (131) or used on its own. For example, in a year-long study of 48 obese stage I-II breast cancer patients, Djuric et al. found weight losses of $<1 \%$ of initial weight in controls, $8.4 \%$ of initial weight with individualized counseling, and $9.8 \%$ of initial weight when individualized counseling was paired with Weight Watchers ${ }^{\circledR}$ group sessions. Two other group-based interventions in breast cancer survivors, i.e., the Healthy Weight Management (HWM) Study ( $\mathrm{n}=85$ ) (132), and the Survivors Health And Physical Exercise (SHAPE) trial $(\mathrm{n}=258)$ (135), tested the impact of a cognitive-behavioral weight loss program plus telephone counseling against a wait-list control. Both interventions resulted in significant improvements in physical activity and weight loss, with the HWM producing an $8 \%$ loss in initial weight at 12 months, and SHAPE invoking a $4.5 \%$ loss of initial body weight at 18 months. The weight loss and increased physical activity were also associated with favorable changes in self-esteem, depression and serum concentrations of sex hormone binding globulin, estradiol, bioavailable estradiol, insulin, leptin and total and LDL 
cholesterol. While far less intensive and the only trial to date to promote weight loss in a broad population of survivors, the Reach-out to Enhance Wellness in Older Survivors (RENEW) trial tested a mailed print and telephone counseling intervention in 641 elderly (age 65+), overweight or obese, long-term (5+ years post-diagnosis) survivors of breast, prostate and colorectal cancer (133). Aims of this trial were to reduce the trajectory of functional decline and incur a slow rate of weight loss $(<1$ pound/week) via a portioncontrolled, low energy density diet (i.e., increased fruit and vegetables, low saturated fat) and increased physical activity. At 12 months, the intervention group as compared to a waitlist control, significantly reduced the rate of functional decline, and improved physical activity, dietary behaviors, and overall quality of life. The intervention group also had an average weight loss of $3 \%$ of initial weight which was sustained over a 2-year period. Factors that likely contributed to the intervention's success were its strong reliance on behavioral theory and intervention contact over an extended period (136).

Elements of each of these trials, as well as DPP and Look Ahead are incorporated into two current trials. The Exercise and Nutrition to Enhance Recovery and Good Health for You (ENERGY) trial is a multi-site trial designed to promote and sustain a 7\% weight loss over a 2 -year period in 800 overweight or obese stage Ic-III breast cancer survivors. The study is strategically designed as a vanguard component of a fully-powered trial of at least 2500 women with breast cancer recurrence endpoints. The group-delivered intervention addresses breast-cancer-specific issues and promotes an energy-restricted diet, plus increased physical activity, behavioral strategies, cognitive restructuring, skills to facilitate and maintain good choices, social support, self-nurturing, and body image and self-acceptance. In the Lifestyle Intervention Study Adjuvant (LISA), a 2-year, telephone-based intervention involving 19 contacts, data showed a significant weight loss in the intervention $(n=165)$ versus control $(\mathrm{n}=158)$ arms, with the following differences noted over time: -4.7 versus $-0.2 \mathrm{~kg}$ at 6 months; -5.5 versus $-0.7 \mathrm{~kg}$ at 12 months; and -3.8 versus $-0.3 \mathrm{~kg}$ at 18 months (134). A full scale adjuvant trial in the North American Breast Cancer Intergroup has been proposed.

In summary, results from diet and weight loss studies conducted to date demonstrate that cancer survivors are motivated and able to make dietary and lifestyle modifications. Individualized counseling (in person or by telephone), group sessions, and tailored mailed materials that are backed by behavioral theory have all proven effective.

\section{Are weight loss and physical activity prescriptions controversial for cancer survivors?}

Until recently, most clinicians focused only on the risk for cancer recurrence and seldom counseled their patients about other chronic or comorbid conditions. As most individuals who are diagnosed with cancer are over age 60 and come to the diagnosis with co-morbid conditions, or acquire them as they age (137), counseling these individuals to achieve and maintain a normal weight and remain physically active as they age makes good sense clinically. Cancer and its treatment are associated with an increased risk for comorbid conditions $(79,138)$, and many survivors successfully treated for their cancer will succumb to heart disease, diabetes, and stroke. Interventions that can help them maintain health and well-being may also improve overall functioning, mood, and help maintain independence with aging.

Many patients and survivors find the experience of cancer a teachable moment - a time to start fresh and improve their overall health. Having made it through the rigors of cancer treatment, they may feel a sense of accomplishment and pride. However, working toward improving fitness and weight can be a lonely process, and encouragement from health professionals (e.g., providing guidance, specific strategies, and setting realistic goals) is 
important. Many patients also will be at risk for second malignancies (e.g., breast, colorectal or other hereditary cancer syndromes, shared risk factors, or as a sequelae of treatment), and may realize benefit from weight reduction, and improved diet, and increased physical activity. Physical training has been shown to be effective for breast cancer patients with lymphedema (139), while obesity has been shown to exacerbate this condition. Thus, there may be many additional reasons for considering weight maintenance/loss programs for survivors.

Currently, we have limited evidence regarding the cancer survival benefits related to weight loss, an improved diet, and increased physical activity; however, maintenance of a normal body weight in adulthood is not controversial as a general health recommendation, and should not be ignored in this patient population. Cancer survivors may derive even more benefit given their increased risk of comorbid conditions. As noted, in several populations of cancer survivors, several controlled trials currently are examining the benefits of weight loss and physical activity, either separately or as part of multicomponent interventions. Until these trials mature, it is reasonable to recommend prevention of weight gain in those who are not underweight, and weight loss to those who are overweight or obese, given generally accepted health benefits. At a minimum, prevention and/or management of comorbid conditions associated with obesity (e.g., diabetes, hypertension, cardiovascular disease) should be an important goal in cancer survivors.

\section{Future directions}

Despite the significant gain in knowledge regarding energy balance and cancer recurrence and survival (Table 1), more research is needed to further elucidate this complex interface. Moving the science forward will require a multifaceted and a multi- or trans-disciplinary approach. Recommendations for future research are presented in Table 3. This research will inform the development of evidence-based guidelines for clinical practice. Meanwhile, several frameworks have been proposed for the prevention and control of obesity, including health policy recommendations for changing the obesogenic environment $(140,141)$. As shown in Figure 2, it is within the larger environment that cancer survivors must manage their physical activity and dietary intake, with ultimate potential effects on target tissue and cancer cells. Within each level of this socioecologic model, there are agonists and antagonists that act in opposition to either create a permissive or hostile environment for the cancer to grow, either in terms of proliferation, metastasis, or in the sheer number of recurrent cases. Thus, both researchers and society at-large need to work together to address the obesity-cancer problem, discerning not only the molecular pathways by which obesity drives cancer progression, but also to develop interventions acting at both individual and societal levels to control obesity in this high-risk population.

\section{Acknowledgments}

Financial Support: CA13148 (WD-W); CA148791 (CLR, WD-W), and CA047888 (CKB)

\section{Select References}

1. Hippocrates of Kos. [cited January 20, 2012]; Available from: http://www.platos-academy.com/ archives/hippocrates.html

2. Haslam D. Obesity: a medical history. Obes Rev. 2007; 8 (Suppl 1):31-6. [PubMed: 17316298]

3. World Cancer Research Fund / American Institute for Cancer Research. Second Expert Report, Food, Nutrition, and Physical Activity, and the Prevention of Cancer: A Global Perspective. Washington, DC: 2007.

4. International Agency for Research on Cancer. Weight Control and Physical Activity. Vol. 6. IARC Press; Lyon: 2002. IARC Handbook of Cancer Prevention. 
5. Cao Y, Ma J. Body mass index, prostate cancer-specific mortality, and biochemical recurrence: a systematic review and meta-analysis. Cancer Prev Res (Phila). 2011; 4:486-501. [PubMed: 21233290]

6. Ewertz M, Jensen MB, Gunnarsdottir KA, Hojris I, Jakobsen EH, Nielsen D, et al. Effect of obesity on prognosis after early-stage breast cancer. J Clin Oncol. 2011; 29:25-31. [PubMed: 21115856]

7. Protani M, Coory M, Martin JH. Effect of obesity on survival of women with breast cancer: systematic review and meta-analysis. Breast Cancer Res Treat. 2010; 123:627-35. [PubMed: 20571870]

8. Sinicrope FA, Foster NR, Sargent DJ, O’Connell MJ, Rankin C. Obesity is an independent prognostic variable in colon cancer survivors. Clin Cancer Res. 2010; 16:1884-93. [PubMed: 20215553]

9. Flegal KM, Carroll MD, Kit BK, Ogden CL. Prevalence of Obesity and Trends in the Distribution of Body Mass Index Among US Adults, 1999-2010. JAMA. 2012

10. World Health Organization (WHO). Obesity and overweight. Fact sheet N`311. Feb. 2011 [cited; Available from: http://www.who.int/mediacentre/factsheets/fs311/en/

11. Institute of Medicine. The Role of Obesity in Cancer Survival and Recurrence: Workshop Summary. Washington, DC: The National Academies Press; 2012.

12. Fearon K, Strasser F, Anker SD, Bosaeus I, Bruera E, Fainsinger RL, et al. Definition and classification of cancer cachexia: an international consensus. Lancet Oncol. 2011; 12:489-95. [PubMed: 21296615]

13. Demark-Wahnefried W, Peterson BL, Winer EP, Marks L, Aziz N, Marcom PK, et al. Changes in weight, body composition, and factors influencing energy balance among premenopausal breast cancer patients receiving adjuvant chemotherapy. J Clin Oncol. 2001; 19:2381-9. [PubMed: 11331316]

14. Brown KA, Simpson ER. Obesity and breast cancer: progress to understanding the relationship. Cancer Res. 2010; 70:4-7. [PubMed: 20028864]

15. Cleary MP, Grossmann ME. Minireview: Obesity and breast cancer: the estrogen connection. Endocrinology. 2009; 150:2537-42. [PubMed: 19372199]

16. McTiernan A. Obesity and cancer: the risks, science, and potential management strategies. Oncology (Williston Park). 2005; 19:871-81. discussion 81-2, 85-6. [PubMed: 16053036]

17. Pike MC, Pearce CL, Wu AH. Prevention of cancers of the breast, endometrium and ovary. Oncogene. 2004; 23:6379-91. [PubMed: 15322512]

18. Hanahan D, Weinberg RA. Hallmarks of cancer: the next generation. Cell. 2011; 144:646-74. [PubMed: 21376230]

19. Duggan C, Irwin ML, Xiao L, Henderson KD, Smith AW, Baumgartner RN, et al. Associations of insulin resistance and adiponectin with mortality in women with breast cancer. J Clin Oncol. 2011; 29:32-9. [PubMed: 21115858]

20. Emaus A, Veierod MB, Tretli S, Finstad SE, Selmer R, Furberg AS, et al. Metabolic profile, physical activity, and mortality in breast cancer patients. Breast Cancer Res Treat. 2010; 121:65160. [PubMed: 19882245]

21. Goodwin PJ, Ennis M, Pritchard KI, Trudeau ME, Koo J, Madarnas Y, et al. Fasting insulin and outcome in early-stage breast cancer: results of a prospective cohort study. J Clin Oncol. 2002; 20:42-51. [PubMed: 11773152]

22. Irwin ML, Duggan C, Wang CY, Smith AW, McTiernan A, Baumgartner RN, et al. Fasting Cpeptide levels and death resulting from all causes and breast cancer: the health, eating, activity, and lifestyle study. J Clin Oncol. 2011; 29:47-53. [PubMed: 21115859]

23. Pasanisi P, Berrino F, De Petris M, Venturelli E, Mastroianni A, Panico S. Metabolic syndrome as a prognostic factor for breast cancer recurrences. Int J Cancer. 2006; 119:236-8. [PubMed: 16450399]

24. Pollak MN, Perdue JF, Margolese RG, Baer K, Richard M. Presence of somatomedin receptors on primary human breast and colon carcinomas. Cancer Lett. 1987; 38:223-30. [PubMed: 2961436]

25. Guo YS, Narayan S, Yallampalli C, Singh P. Characterization of insulinlike growth factor I receptors in human colon cancer. Gastroenterology. 1992; 102:1101-8. [PubMed: 1312970] 
26. Koenuma M, Yamori T, Tsuruo T. Insulin and insulin-like growth factor 1 stimulate proliferation of metastatic variants of colon carcinoma 26. Jpn J Cancer Res. 1989; 80:51-8. [PubMed: 2540132]

27. Bjork J, Nilsson J, Hultcrantz R, Johansson C. Growth-regulatory effects of sensory neuropeptides, epidermal growth factor, insulin, and somatostatin on the non-transformed intestinal epithelial cell line IEC-6 and the colon cancer cell line HT 29. Scand J Gastroenterol. 1993; 28:879-84. [PubMed: 7505479]

28. Watkins LF, Lewis LR, Levine AE. Characterization of the synergistic effect of insulin and transferrin and the regulation of their receptors on a human colon carcinoma cell line. Int J Cancer. 1990; 45:372-5. [PubMed: 2406206]

29. Giovannucci E. Insulin and colon cancer. Cancer Causes Control. 1995; 6:164-79. [PubMed: 7749056]

30. Giovannucci E. Insulin, insulin-like growth factors and colon cancer: a review of the evidence. J Nutr. 2001; 131:3109S-20S. [PubMed: 11694656]

31. Kaaks R, Lukanova A. Energy balance and cancer: the role of insulin and insulin-like growth factor-I. Proc Nutr Soc. 2001; 60:91-106. [PubMed: 11310428]

32. Pritchard KI, Shepherd LE, Chapman JA, Norris BD, Cantin J, Goss PE, et al. Randomized trial of tamoxifen versus combined tamoxifen and octreotide LAR Therapy in the adjuvant treatment of early-stage breast cancer in postmenopausal women: NCIC CTG MA.14. J Clin Oncol. 2011; 29:3869-76. [PubMed: 21911723]

33. Law JH, Habibi G, Hu K, Masoudi H, Wang MY, Stratford AL, et al. Phosphorylated insulin-like growth factor-i/insulin receptor is present in all breast cancer subtypes and is related to poor survival. Cancer Res. 2008; 68:10238-46. [PubMed: 19074892]

34. Wolpin BM, Meyerhardt JA, Chan AT, Ng K, Chan JA, Wu K, et al. Insulin, the insulin-like growth factor axis, and mortality in patients with nonmetastatic colorectal cancer. J Clin Oncol. 2009; 27:176-85. [PubMed: 19064975]

35. Goodwin PJ, Ennis M, Pritchard KI, Trudeau ME, Koo J, Taylor SK, et al. Insulin- and obesityrelated variables in early-stage breast cancer: correlations and time course of prognostic associations. J Clin Oncol. 2012; 30:164-71. [PubMed: 22162568]

36. Slattery ML, Fitzpatrick FA. Convergence of hormones, inflammation, and energy-related factors: a novel pathway of cancer etiology. Cancer Prev Res (Phila). 2009; 2:922-30. [PubMed: 19892662]

37. Moreschi C. Beziehungen zwischen ernährung und tumorwachstum. Z Immunitätsforsch Orig. 1909; 2:651-75.

38. Hursting SD, Lavigne JA, Berrigan D, Perkins SN, Barrett JC. Calorie restriction, aging, and cancer prevention: mechanisms of action and applicability to humans. Annu Rev Med. 2003; 54:131-52. [PubMed: 12525670]

39. Tannenbaum A. The genesis and growth of tumors. II. Effects of caloric restriction per se. Cancer Res. 1942; 2:460-7.

40. Welsch MA, Cohen LA, Welsch CW. Inhibition of growth of human breast carcinoma xenografts by energy expenditure via voluntary exercise in athymic mice fed a high-fat diet. Nutr Cancer. 1995; 23:309-18. [PubMed: 7603891]

41. Zheng X, Cui XX, Huang MT, Liu Y, Shih WJ, Lin Y, et al. Inhibitory effect of voluntary running wheel exercise on the growth of human pancreatic Panc-1 and prostate PC-3 xenograft tumors in immunodeficient mice. Oncol Rep. 2008; 19:1583-8. [PubMed: 18497969]

42. Jones LW, Eves ND, Courneya KS, Chiu BK, Baracos VE, Hanson J, et al. Effects of exercise training on antitumor efficacy of doxorubicin in MDA-MB-231 breast cancer xenografts. Clin Cancer Res. 2005; 11:6695-8. [PubMed: 16166449]

43. Colbert LH, Mai V, Perkins SN, Berrigan D, Lavigne JA, Wimbrow HH, et al. Exercise and intestinal polyp development in APCMin mice. Med Sci Sports Exerc. 2003; 35:1662-9. [PubMed: 14523302]

44. Padovani M, Lavigne JA, Chandramouli GV, Perkins SN, Barrett JC, Hursting SD, et al. Distinct effects of calorie restriction and exercise on mammary gland gene expression in C57BL/6 mice. Cancer Prev Res (Phila). 2009; 2:1076-87. [PubMed: 19952363] 
45. Rock CL, Doyle C, Demark-Wahnefried W, Meyerhardt J, Courneya KS, Schwartz AL, et al. Nutrition and physical activity guidelines for cancer survivors. CA: a cancer journal for clinicians. 2012

46. von Gruenigen VE, Tian C, Frasure H, Waggoner S, Keys H, Barakat RR. Treatment effects, disease recurrence, and survival in obese women with early endometrial carcinoma : a Gynecologic Oncology Group study. Cancer. 2006; 107:2786-91. [PubMed: 17096437]

47. Calle EE, Rodriguez C, Walker-Thurmond K, Thun MJ. Overweight, obesity, and mortality from cancer in a prospectively studied cohort of U.S. adults. N Engl J Med. 2003; 348:1625-38. [PubMed: 12711737]

48. Giovannucci E, Liu Y, Platz EA, Stampfer MJ, Willett WC. Risk factors for prostate cancer incidence and progression in the health professionals follow-up study. Int J Cancer. 2007; 121:1571-8. [PubMed: 17450530]

49. Wright ME, Chang SC, Schatzkin A, Albanes D, Kipnis V, Mouw T, et al. Prospective study of adiposity and weight change in relation to prostate cancer incidence and mortality. Cancer. 2007; 109:675-84. [PubMed: 17211863]

50. Meyerhardt JA, Catalano PJ, Haller DG, Mayer RJ, Benson AB 3rd, Macdonald JS, et al. Influence of body mass index on outcomes and treatment-related toxicity in patients with colon carcinoma. Cancer. 2003; 98:484-95. [PubMed: 12879464]

51. Meyerhardt JA, Niedzwiecki D, Hollis D, Saltz LB, Mayer RJ, Nelson H, et al. Impact of body mass index and weight change after treatment on cancer recurrence and survival in patients with stage III colon cancer: findings from Cancer and Leukemia Group B 89803. J Clin Oncol. 2008; 26:4109-15. [PubMed: 18757324]

52. Meyerhardt JA, Tepper JE, Niedzwiecki D, Hollis DR, McCollum AD, Brady D, et al. Impact of body mass index on outcomes and treatment-related toxicity in patients with stage II and III rectal cancer: findings from Intergroup Trial 0114. J Clin Oncol. 2004; 22:648-57. [PubMed: 14966087]

53. Dignam JJ, Polite BN, Yothers G, Raich P, Colangelo L, O’Connell MJ, et al. Body mass index and outcomes in patients who receive adjuvant chemotherapy for colon cancer. J Natl Cancer Inst. 2006; 98:1647-54. [PubMed: 17105987]

54. Shibakita M, Yoshimura H, Tachibana M, Ueda S, Nagasue N. Body mass index influences longterm outcome in patients with colorectal cancer. Hepatogastroenterology. 2010; 57:62-9. [PubMed: 20422873]

55. Hines RB, Shanmugam C, Waterbor JW, McGwin G Jr, Funkhouser E, Coffey CS, et al. Effect of comorbidity and body mass index on the survival of African-American and Caucasian patients with colon cancer. Cancer. 2009; 115:5798-806. [PubMed: 19937953]

56. Campbell PT, Newton CC, Dehal AN, Jacobs EJ, Patel AV, Gapstur SM. Impact of body mass index on survival after colorectal cancer diagnosis: the Cancer Prevention Study-II Nutrition Cohort. J Clin Oncol. 2012; 30:42-52. [PubMed: 22124093]

57. Rock CL, Demark-Wahnefried W. Nutrition and survival after the diagnosis of breast cancer: a review of the evidence. J Clin Oncol. 2002; 20:3302-16. [PubMed: 12149305]

58. Patterson RE, Cadmus LA, Emond JA, Pierce JP. Physical activity, diet, adiposity and female breast cancer prognosis: a review of the epidemiologic literature. Maturitas. 2010; 66:5-15. [PubMed: 20097494]

59. Meyerhardt JA, Niedzwiecki D, Hollis D, Saltz LB, Hu FB, Mayer RJ, et al. Association of dietary patterns with cancer recurrence and survival in patients with stage III colon cancer. JAMA. 2007; 298:754-64. [PubMed: 17699009]

60. Berkow SE, Barnard ND, Saxe GA, Ankerberg-Nobis T. Diet and survival after prostate cancer diagnosis. Nutr Rev. 2007; 65:391-403. [PubMed: 17958206]

61. Davies NJ, Batehup L, Thomas R. The role of diet and physical activity in breast, colorectal, and prostate cancer survivorship: a review of the literature. Br J Cancer. 2011; 105 (Suppl 1):S52-73. [PubMed: 22048034]

62. Meyerhardt JA, Ma J, Courneya KS. Energetics in colorectal and prostate cancer. J Clin Oncol. 2010; 28:4066-73. [PubMed: 20644082]

63. Holmes MD, Chen WY, Feskanich D, Kroenke CH, Colditz GA. Physical activity and survival after breast cancer diagnosis. JAMA. 2005; 293:2479-86. [PubMed: 15914748] 
64. Meyerhardt JA, Giovannucci EL, Holmes MD, Chan AT, Chan JA, Colditz GA, et al. Physical activity and survival after colorectal cancer diagnosis. J Clin Oncol. 2006; 24:3527-34. [PubMed: 16822844]

65. Meyerhardt JA, Giovannucci EL, Ogino S, Kirkner GJ, Chan AT, Willett W, et al. Physical activity and male colorectal cancer survival. Arch Intern Med. 2009; 169:2102-8. [PubMed: 20008694]

66. Kenfield SA, Stampfer MJ, Giovannucci E, Chan JM. Physical activity and survival after prostate cancer diagnosis in the health professionals follow-up study. J Clin Oncol. 2011; 29:726-32. [PubMed: 21205749]

67. Richman EL, Kenfield SA, Stampfer MJ, Paciorek A, Carroll PR, Chan JM. Physical activity after diagnosis and risk of prostate cancer progression: data from the cancer of the prostate strategic urologic research endeavor. Cancer Res. 2011; 71:3889-95. [PubMed: 21610110]

68. Chen X, Lu W, Zheng W, Gu K, Matthews CE, Chen Z, et al. Exercise after diagnosis of breast cancer in association with survival. Cancer Prev Res (Phila). 2011; 4:1409-18. [PubMed: 21795422]

69. Holick CN, Newcomb PA, Trentham-Dietz A, Titus-Ernstoff L, Bersch AJ, Stampfer MJ, et al. Physical activity and survival after diagnosis of invasive breast cancer. Cancer Epidemiol Biomarkers Prev. 2008; 17:379-86. [PubMed: 18250341]

70. Irwin ML, Smith AW, McTiernan A, Ballard-Barbash R, Cronin K, Gilliland FD, et al. Influence of pre- and postdiagnosis physical activity on mortality in breast cancer survivors: the health, eating, activity, and lifestyle study. J Clin Oncol. 2008; 26:3958-64. [PubMed: 18711185]

71. Pierce JP, Stefanick ML, Flatt SW, Natarajan L, Sternfeld B, Madlensky L, et al. Greater survival after breast cancer in physically active women with high vegetable-fruit intake regardless of obesity. J Clin Oncol. 2007; 25:2345-51. [PubMed: 17557947]

72. Sternfeld B, Weltzien E, Quesenberry CP Jr, Castillo AL, Kwan M, Slattery ML, et al. Physical activity and risk of recurrence and mortality in breast cancer survivors: findings from the LACE study. Cancer Epidemiol Biomarkers Prev. 2009; 18:87-95. [PubMed: 19124485]

73. Irwin ML, McTiernan A, Manson JE, Thomson CA, Sternfeld B, Stefanick ML, et al. Physical activity and survival in postmenopausal women with breast cancer: results from the women's health initiative. Cancer Prev Res (Phila). 2011; 4:522-9. [PubMed: 21464032]

74. Meyerhardt JA, Heseltine D, Niedzwiecki D, Hollis D, Saltz LB, Mayer RJ, et al. Impact of physical activity on cancer recurrence and survival in patients with stage III colon cancer: findings from CALGB 89803. J Clin Oncol. 2006; 24:3535-41. [PubMed: 16822843]

75. Irwin ML, Varma K, Alvarez-Reeves M, Cadmus L, Wiley A, Chung GG, et al. Randomized controlled trial of aerobic exercise on insulin and insulin-like growth factors in breast cancer survivors: the Yale Exercise and Survivorship study. Cancer Epidemiol Biomarkers Prev. 2009; 18:306-13. [PubMed: 19124513]

76. Ligibel JA, Campbell N, Partridge A, Chen WY, Salinardi T, Chen H, et al. Impact of a mixed strength and endurance exercise intervention on insulin levels in breast cancer survivors. J Clin Oncol. 2008; 26:907-12. [PubMed: 18281663]

77. Blanchard CM, Courneya KS, Stein K. Cancer survivors' adherence to lifestyle behavior recommendations and associations with health-related quality of life: results from the American Cancer Society's SCS-II. J Clin Oncol. 2008; 26:2198-204. [PubMed: 18445845]

78. Griggs JJ, Culakova E, Sorbero ME, van Ryn M, Poniewierski MS, Wolff DA, et al. Effect of patient socioeconomic status and body mass index on the quality of breast cancer adjuvant chemotherapy. J Clin Oncol. 2007; 25:277-84. [PubMed: 17159190]

79. Klabunde CN, Legler JM, Warren JL, Baldwin LM, Schrag D. A refined comorbidity measurement algorithm for claims-based studies of breast, prostate, colorectal, and lung cancer patients. Ann Epidemiol. 2007; 17:584-90. [PubMed: 17531502]

80. van de Poll-Franse LV, Houterman S, Janssen-Heijnen ML, Dercksen MW, Coebergh JW, Haak HR. Less aggressive treatment and worse overall survival in cancer patients with diabetes: a large population based analysis. Int J Cancer. 2007; 120:1986-92. [PubMed: 17230509] 
81. Peairs KS, Barone BB, Snyder CF, Yeh HC, Stein KB, Derr RL, et al. Diabetes mellitus and breast cancer outcomes: a systematic review and meta-analysis. J Clin Oncol. 2011; 29:40-6. [PubMed: 21115865]

82. Goodwin PJ, Stambolic V, Lemieux J, Chen BE, Parulekar WR, Gelmon KA, et al. Evaluation of metformin in early breast cancer: a modification of the traditional paradigm for clinical testing of anti-cancer agents. Breast Cancer Res Treat. 2011; 126:215-20. [PubMed: 20976543]

83. Flegal KM, Carroll MD, Kuczmarski RJ, Johnson CL. Overweight and obesity in the United States: prevalence and trends, 1960-1994. Int J Obes Relat Metab Disord. 1998; 22:39-47. [PubMed: 9481598]

84. The Practical Guide. Identification, Evaluation, and Treatment of Overweight and Obesity in Adults. National Institutes of Health; 2000.

85. U S. Preventive Services Taskforce. Screening for obesity in adults: recommendations and rationale. Ann Intern Med. 2003; 139:930-2. [PubMed: 14644896]

86. Leblanc ES, O'Connor E, Whitlock EP, Patnode CD, Kapka T. Effectiveness of primary carerelevant treatments for obesity in adults: a systematic evidence review for the U.S. Preventive Services Task Force. Ann Intern Med. 2011; 155:434-47. [PubMed: 21969342]

87. Sacks FM, Bray GA, Carey VJ, Smith SR, Ryan DH, Anton SD, et al. Comparison of weight-loss diets with different compositions of fat, protein, and carbohydrates. N Engl J Med. 2009; 360:85973. [PubMed: 19246357]

88. Foster GD, Wyatt HR, Hill JO, Makris AP, Rosenbaum DL, Brill C, et al. Weight and metabolic outcomes after 2 years on a low-carbohydrate versus low-fat diet: a randomized trial. Ann Intern Med. 2010; 153:147-57. [PubMed: 20679559]

89. Wadden TA, Webb VL, Moran CH, Bailer BA. Lifestyle modification for obesity: new developments in diet, physical activity, and behavior therapy. Circulation. in press.

90. Kushi LH, Byers T, Doyle C, Bandera EV, McCullough M, McTiernan A, et al. American Cancer Society Guidelines on Nutrition and Physical Activity for cancer prevention: reducing the risk of cancer with healthy food choices and physical activity. CA Cancer J Clin. 2006; 56:254-81. quiz 313-4. [PubMed: 17005596]

91. Donnelly JE, Blair SN, Jakicic JM, Manore MM, Rankin JW, Smith BK. American College of Sports Medicine Position Stand. Appropriate physical activity intervention strategies for weight loss and prevention of weight regain for adults. Med Sci Sports Exerc. 2009; 41:459-71. [PubMed: 19127177]

92. Perri MG, McAllister DA, Gange JJ, Jordan RC, McAdoo G, Nezu AM. Effects of four maintenance programs on the long-term management of obesity. J Consult Clin Psychol. 1988; 56:529-34. [PubMed: 2848874]

93. Knowler WC, Barrett-Connor E, Fowler SE, Hamman RF, Lachin JM, Walker EA, et al. Reduction in the incidence of type 2 diabetes with lifestyle intervention or metformin. N Engl J Med. 2002; 346:393-403. [PubMed: 11832527]

94. Ryan DH, Espeland MA, Foster GD, Haffner SM, Hubbard VS, Johnson KC, et al. Look AHEAD (Action for Health in Diabetes): design and methods for a clinical trial of weight loss for the prevention of cardiovascular disease in type 2 diabetes. Control Clin Trials. 2003; 24:610-28. [PubMed: 14500058]

95. Pi-Sunyer X, Blackburn G, Brancati FL, Bray GA, Bright R, Clark JM, et al. Reduction in weight and cardiovascular disease risk factors in individuals with type 2 diabetes: one-year results of the look AHEAD trial. Diabetes Care. 2007; 30:1374-83. [PubMed: 17363746]

96. Appel LJ, Clark JM, Yeh HC, Wang NY, Coughlin JW, Daumit G, et al. Comparative effectiveness of weight-loss interventions in clinical practice. N Engl J Med. 2011; 365:1959-68. [PubMed: 22085317]

97. Wing RR. Long-term effects of a lifestyle intervention on weight and cardiovascular risk factors in individuals with type 2 diabetes mellitus: four-year results of the Look AHEAD trial. Arch Intern Med. 2010; 170:1566-75. [PubMed: 20876408]

98. Kaplan LM. Pharmacological therapies for obesity. Gastroenterol Clin North Am. 2005; 34:91104. [PubMed: 15823441] 
99. Hollander PA, Elbein SC, Hirsch IB, Kelley D, McGill J, Taylor T, et al. Role of orlistat in the treatment of obese patients with type 2 diabetes. A 1-year randomized double-blind study. Diabetes Care. 1998; 21:1288-94. [PubMed: 9702435]

100. Li Z, Maglione M, Tu W, Mojica W, Arterburn D, Shugarman LR, et al. Meta-analysis: pharmacologic treatment of obesity. Ann Intern Med. 2005; 142:532-46. [PubMed: 15809465]

101. Sjostrom L, Narbro K, Sjostrom CD, Karason K, Larsson B, Wedel H, et al. Effects of bariatric surgery on mortality in Swedish obese subjects. N Engl J Med. 2007; 357:741-52. [PubMed: 17715408]

102. Wadden TA, Berkowitz RI, Womble LG, Sarwer DB, Phelan S, Cato RK, et al. Randomized trial of lifestyle modification and pharmacotherapy for obesity. N Engl J Med. 2005; 353:2111-20. [PubMed: 16291981]

103. Adams TD, Gress RE, Smith SC, Halverson RC, Simper SC, Rosamond WD, et al. Long-term mortality after gastric bypass surgery. N Engl J Med. 2007; 357:753-61. [PubMed: 17715409]

104. Smith BR, Schauer P, Nguyen NT. Surgical approaches to the treatment of obesity: bariatric surgery. Endocrinol Metab Clin North Am. 2008; 37:943-64. [PubMed: 19026941]

105. Flegal KM, Carroll MD, Ogden CL, Curtin LR. Prevalence and trends in obesity among US adults, 1999-2008. JAMA. 2010; 303:235-41. [PubMed: 20071471]

106. Santry HP, Gillen DL, Lauderdale DS. Trends in bariatric surgical procedures. JAMA. 2005; 294:1909-17. [PubMed: 16234497]

107. Flum DR, Belle SH, King WC, Wahed AS, Berk P, Chapman W, et al. Perioperative safety in the longitudinal assessment of bariatric surgery. N Engl J Med. 2009; 361:445-54. [PubMed: 19641201]

108. Ashrafian H, Ahmed K, Rowland SP, Patel VM, Gooderham NJ, Holmes E, et al. Metabolic surgery and cancer: protective effects of bariatric procedures. Cancer. 2011; 117:1788-99. [PubMed: 21509756]

109. Sjostrom L, Gummesson A, Sjostrom CD, Narbro K, Peltonen M, Wedel H, et al. Effects of bariatric surgery on cancer incidence in obese patients in Sweden (Swedish Obese Subjects Study): a prospective, controlled intervention trial. Lancet Oncol. 2009; 10:653-62. [PubMed: 19556163]

110. Shade ED, Ulrich CM, Wener MH, Wood B, Yasui Y, Lacroix K, et al. Frequent intentional weight loss is associated with lower natural killer cell cytotoxicity in postmenopausal women: possible long-term immune effects. J Am Diet Assoc. 2004; 104:903-12. [PubMed: 15175588]

111. Denlinger CS, Barsevick AM. The challenges of colorectal cancer survivorship. J Natl Compr Canc Netw. 2009; 7:883-93. quiz 94. [PubMed: 19755048]

112. Harrington CB, Hansen JA, Moskowitz M, Todd BL, Feuerstein M. It's not over when it's over: long-term symptoms in cancer survivors--a systematic review. Int J Psychiatry Med. 2010; 40:163-81. [PubMed: 20848873]

113. Shi Q, Smith TG, Michonski JD, Stein KD, Kaw C, Cleeland CS. Symptom burden in cancer survivors 1 year after diagnosis: a report from the American Cancer Society's Studies of Cancer Survivors. Cancer. 2011; 117:2779-90. [PubMed: 21495026]

114. Ashing-Giwa KT, Padilla G, Tejero J, Kraemer J, Wright K, Coscarelli A, et al. Understanding the breast cancer experience of women: a qualitative study of African American, Asian American, Latina and Caucasian cancer survivors. Psychooncology. 2004; 13:408-28. [PubMed: 15188447]

115. Schmitz KH, Courneya KS, Matthews C, Demark-Wahnefried W, Galvao DA, Pinto BM, et al. American College of Sports Medicine roundtable on exercise guidelines for cancer survivors. Med Sci Sports Exerc. 2010; 42:1409-26. [PubMed: 20559064]

116. Zabora J, BrintzenhofeSzoc K, Curbow B, Hooker C, Piantadosi S. The prevalence of psychological distress by cancer site. Psychooncology. 2001; 10:19-28. [PubMed: 11180574]

117. Demark-Wahnefried W, Bowen DJ, Jabson JM, Paskett ED. Scientific bias arising from sampling, selective recruitment, and attrition: the case for improved reporting. Cancer Epidemiol Biomarkers Prev. 2011; 20:415-8. [PubMed: 21382981]

118. Physical Activity Guidelines Advisory Committee report, 2008. To the Secretary of Health and Human Services. Part A: executive summary. Nutr Rev. 2009; 67:114-20. [PubMed: 19178654] 
119. Speck RM, Courneya KS, Masse LC, Duval S, Schmitz KH. An update of controlled physical activity trials in cancer survivors: a systematic review and meta-analysis. J Cancer Surviv. 2010; 4:87-100. [PubMed: 20052559]

120. Brown JC, Huedo-Medina TB, Pescatello LS, Pescatello SM, Ferrer RA, Johnson BT. Efficacy of exercise interventions in modulating cancer-related fatigue among adult cancer survivors: a metaanalysis. Cancer Epidemiol Biomarkers Prev. 2011; 20:123-33. [PubMed: 21051654]

121. Craft LL, Vaniterson EH, Helenowski IB, Rademaker AW, Courneya KS. Exercise Effects on Depressive Symptoms in Cancer Survivors: A Systematic Review and Meta-analysis. Cancer Epidemiol Biomarkers Prev. 2012; 21:3-19. [PubMed: 22068286]

122. Ferrer RA, Huedo-Medina TB, Johnson BT, Ryan S, Pescatello LS. Exercise interventions for cancer survivors: a meta-analysis of quality of life outcomes. Ann Behav Med. 2011; 41:32-47. [PubMed: 20931309]

123. Courneya KS, Booth CM, Gill S, O’Brien P, Vardy J, Friedenreich CM, et al. The Colon Health and Life-Long Exercise Change trial: a randomized trial of the National Cancer Institute of Canada Clinical Trials Group. Curr Oncol. 2008; 15:279-85. [PubMed: 19079628]

124. Chlebowski RT, Blackburn GL, Thomson CA, Nixon DW, Shapiro A, Hoy MK, et al. Dietary fat reduction and breast cancer outcome: interim efficacy results from the Women's Intervention Nutrition Study. J Natl Cancer Inst. 2006; 98:1767-76. [PubMed: 17179478]

125. Pierce JP, Natarajan L, Caan BJ, Parker BA, Greenberg ER, Flatt SW, et al. Influence of a diet very high in vegetables, fruit, and fiber and low in fat on prognosis following treatment for breast cancer: the Women's Healthy Eating and Living (WHEL) randomized trial. JAMA. 2007; 298:289-98. [PubMed: 17635889]

126. Demark-Wahnefried W, Clipp EC, Lipkus IM, Lobach D, Snyder DC, Sloane R, et al. Main outcomes of the FRESH START trial: a sequentially tailored, diet and exercise mailed print intervention among breast and prostate cancer survivors. J Clin Oncol. 2007; 25:2709-18. [PubMed: 17602076]

127. Demark-Wahnefried W, Case LD, Blackwell K, Marcom PK, Kraus W, Aziz N, et al. Results of a diet/exercise feasibility trial to prevent adverse body composition change in breast cancer patients on adjuvant chemotherapy. Clin Breast Cancer. 2008; 8:70-9. [PubMed: 18501061]

128. Loprinzi CL, Athmann LM, Kardinal CG, O’Fallon JR, See JA, Bruce BK, et al. Randomized trial of dietician counseling to try to prevent weight gain associated with breast cancer adjuvant chemotherapy. Oncology. 1996; 53:228-32. [PubMed: 8643226]

129. Djuric Z, Ellsworth JS, Weldon AL, Ren J, Richardson CR, Resnicow K, et al. A Diet and Exercise Intervention during Chemotherapy for Breast Cancer. Open Obes J. 2011; 3:87-97. [PubMed: 22238561]

130. de Waard F, Ramlau R, Mulders Y, de Vries T, van Waveren S. A feasibility study on weight reduction in obese postmenopausal breast cancer patients. Eur J Cancer Prev. 1993; 2:233-8. [PubMed: 8490542]

131. Djuric Z, DiLaura NM, Jenkins I, Darga L, Jen CK, Mood D, et al. Combining weight-loss counseling with the weight watchers plan for obese breast cancer survivors. Obes Res. 2002; 10:657-65. [PubMed: 12105288]

132. Mefferd K, Nichols JF, Pakiz B, Rock CL. A cognitive behavioral therapy intervention to promote weight loss improves body composition and blood lipid profiles among overweight breast cancer survivors. Breast Cancer Res Treat. 2007; 104:145-52. [PubMed: 17058023]

133. Morey MC, Snyder DC, Sloane R, Cohen HJ, Peterson B, Hartman TJ, et al. Effects of homebased diet and exercise on functional outcomes among older, overweight long-term cancer survivors: RENEW: a randomized controlled trial. JAMA. 2009; 301:1883-91. [PubMed: 19436015]

134. Ontario Clinical Oncology Group (OCOG). Lifestyle intervention study in adjuvant treatment of early breast cancer (LISA). Clinicaltrialsgov.

135. Taylor DL, Nichols JF, Pakiz B, Bardwell WA, Flatt SW, Rock CL. Relationships between cardiorespiratory fitness, physical activity, and psychosocial variables in overweight and obese breast cancer survivors. Int J Behav Med. 2010; 17:264-70. [PubMed: 20177847] 
136. Demark-Wahnefried W, Morey MC, Sloane R, Snyder DC, Miller PE, Hartman TJ, et al. Reach Out to Enhance Wellness Home-Based Diet-Exercise Intervention Promotes Reproducible and Sustainable Long-Term Improvements in Health Behaviors, Body Weight, and Physical Functioning in Older, Overweight/Obese Cancer Survivors. J Clin Oncol. 2012 May 21. [Epub ahead of print].

137. Pal SK, Hurria A. Impact of age, sex, and comorbidity on cancer therapy and disease progression. J Clin Oncol. 2010; 28:4086-93. [PubMed: 20644100]

138. Yabroff KR, Lawrence WF, Clauser S, Davis WW, Brown ML. Burden of illness in cancer survivors: findings from a population-based national sample. J Natl Cancer Inst. 2004; 96:132230. [PubMed: 15339970]

139. Schmitz KH, Ahmed RL, Troxel A, Cheville A, Smith R, Lewis-Grant L, et al. Weight lifting in women with breast-cancer-related lymphedema. N Engl J Med. 2009; 361:664-73. [PubMed: 19675330]

140. Gortmaker SL, Swinburn BA, Levy D, Carter R, Mabry PL, Finegood DT, et al. Changing the future of obesity: science, policy, and action. Lancet. 2011; 378:838-47. [PubMed: 21872752]

141. Sacks G, Swinburn B, Lawrence M. Obesity Policy Action framework and analysis grids for a comprehensive policy approach to reducing obesity. Obes Rev. 2009; 10:76-86. [PubMed: 18761640] 


\section{Energy Balance \\ Resting Metabolic Rate \\ Energy needed to maintain body function at rest. Accounts for $60-75 \%$ of expenditure. Modified by lean body mass (age), and external/internal temperature.

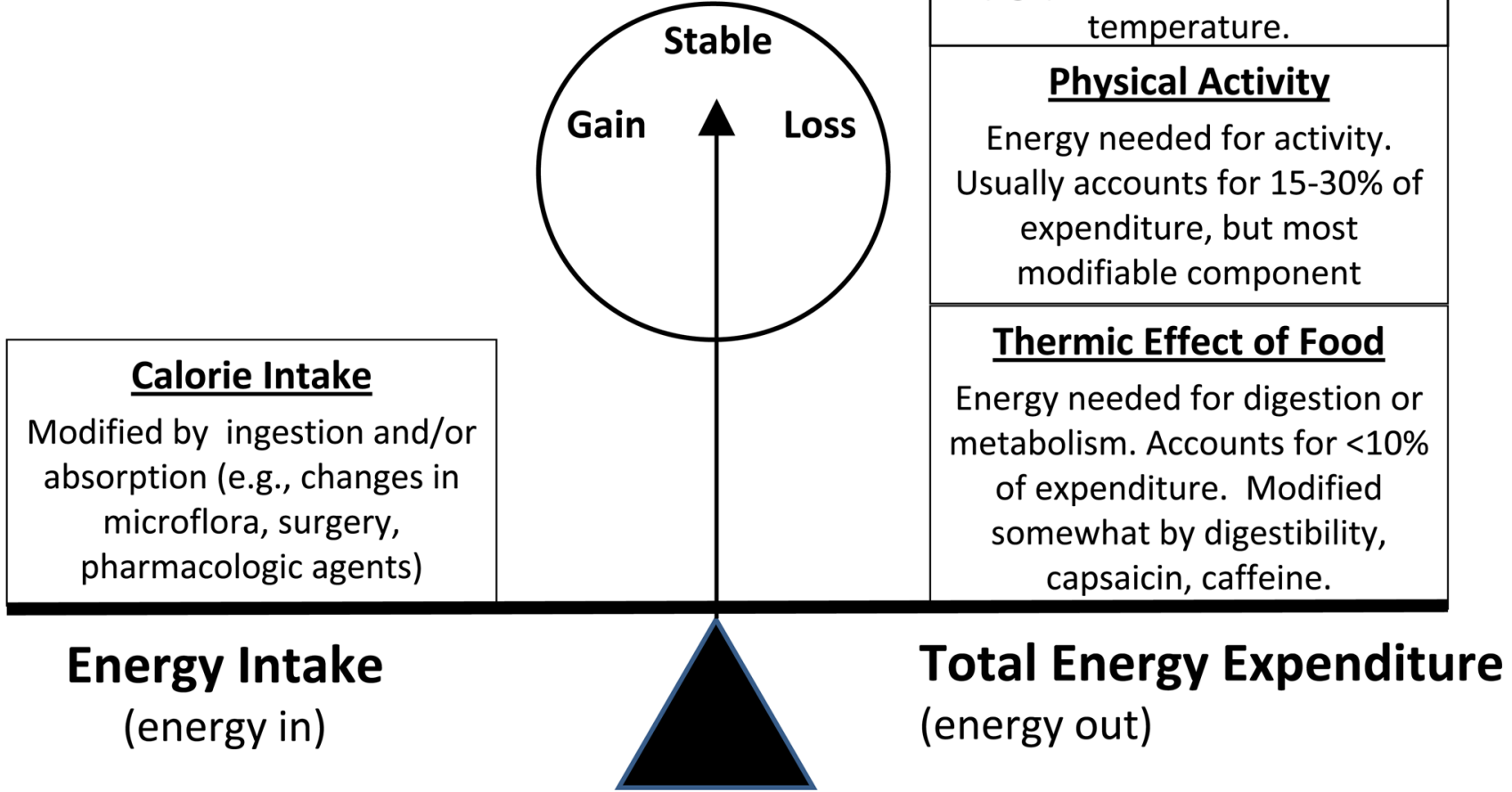

Figure 1.

The Complex Dynamic Nature of Energy Balance: Energy balance occurs when energy intake (measured in kilocalories) equals total energy expenditure (resting metabolic rate + physical activity + thermic effect of food), with gains and losses occurring when there is an imbalance. A gain of one pound occurs when approximately 3,500 calories are consumed in excess of energy needs. 


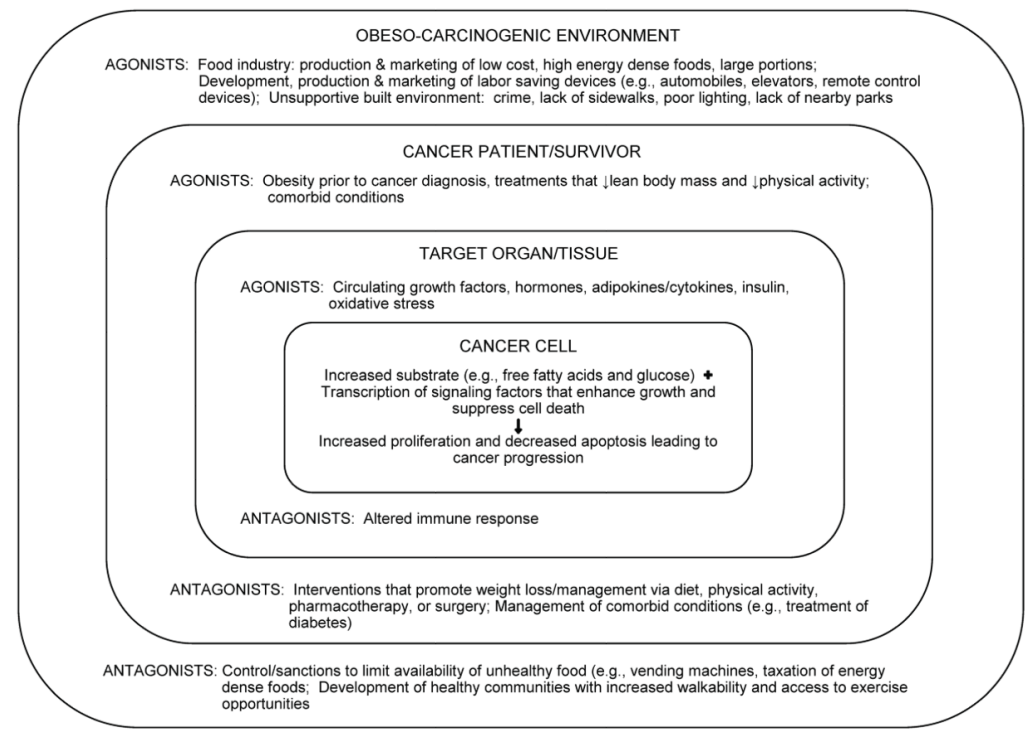

Figure 2.

Cancer progression ultimately is a product of the larger environment. High energy dense foods are foods high in energy (calories) per gram weight, e.g., fried foods (high in fat) whereas fruits and vegetables are low energy dense foods. 


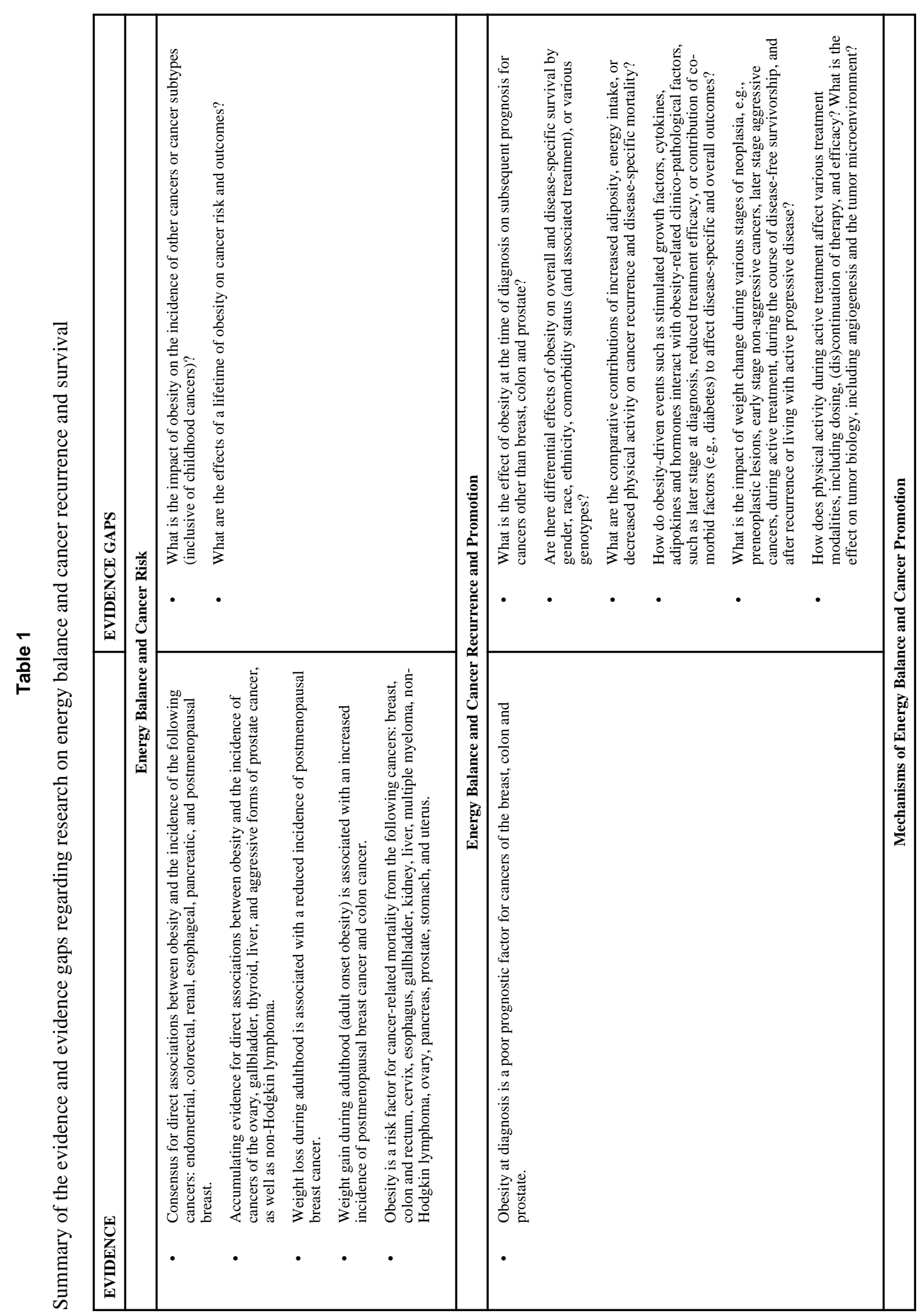

Cancer Epidemiol Biomarkers Prev. Author manuscript; available in PMC 2013 August 01. 


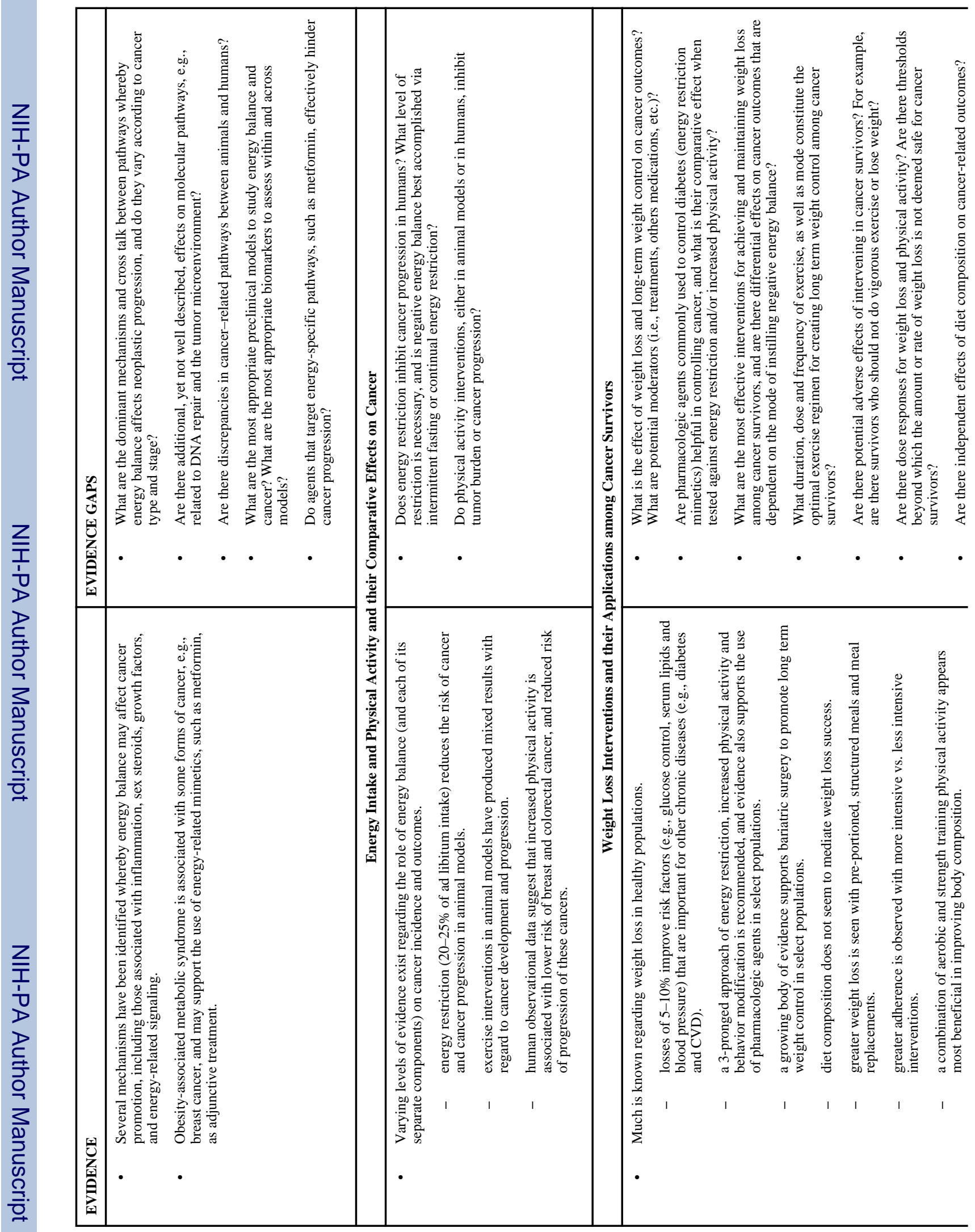




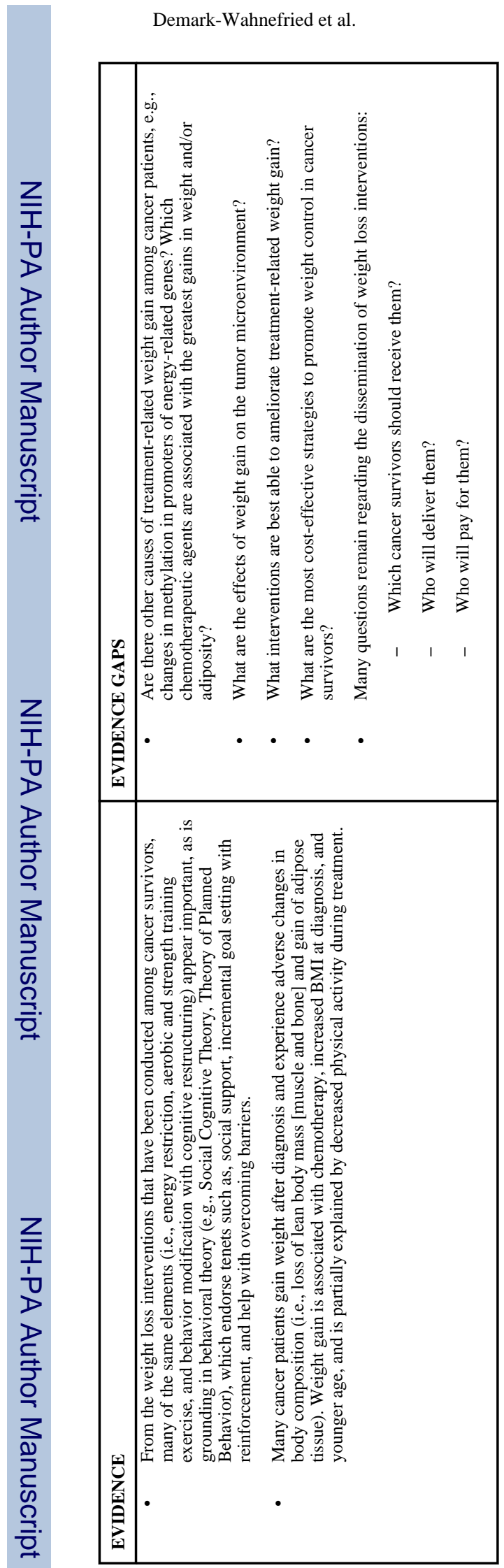

Page 24

Cancer Epidemiol Biomarkers Prev. Author manuscript; available in PMC 2013 August 01. 


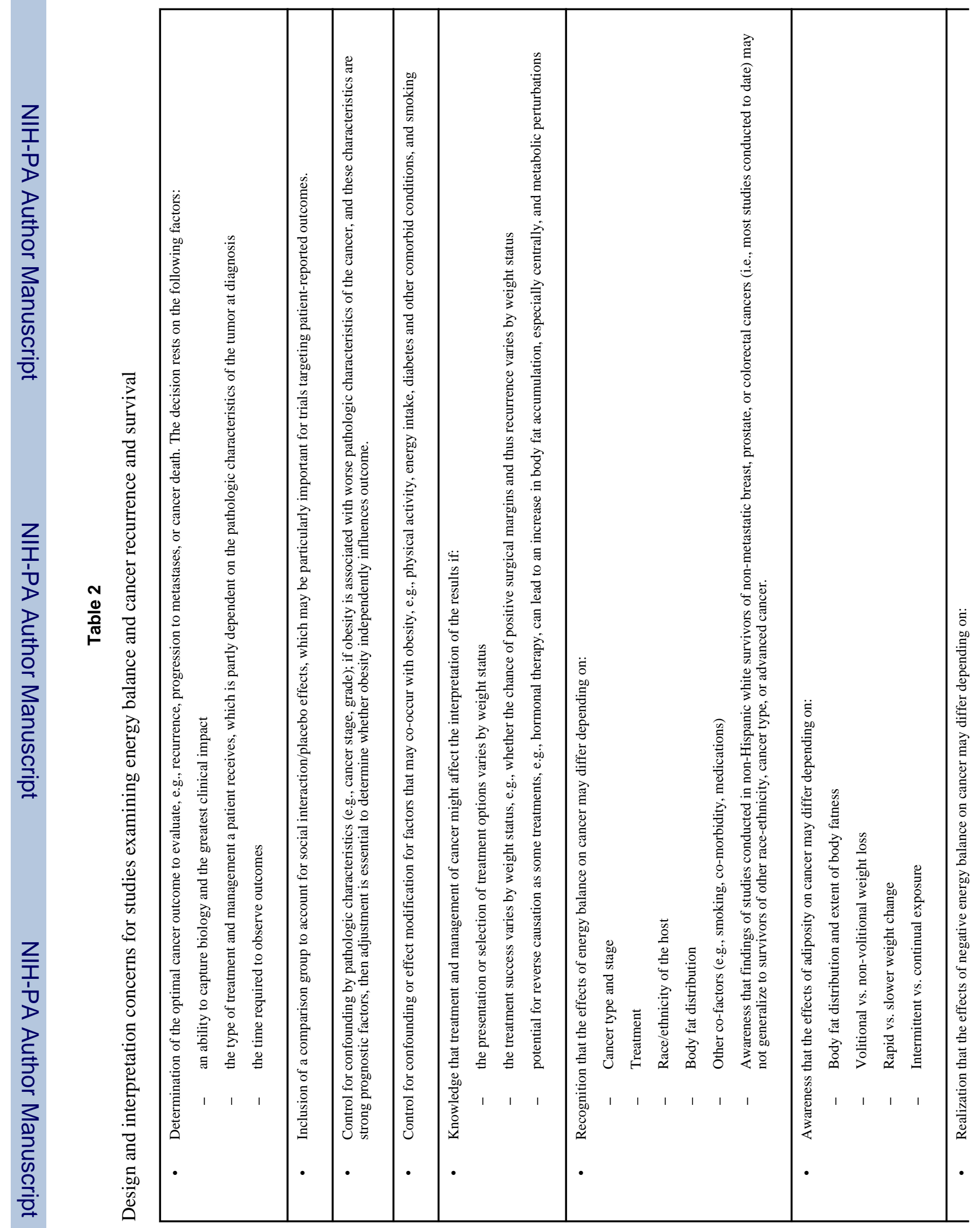

Cancer Epidemiol Biomarkers Prev. Author manuscript; available in PMC 2013 August 01. 


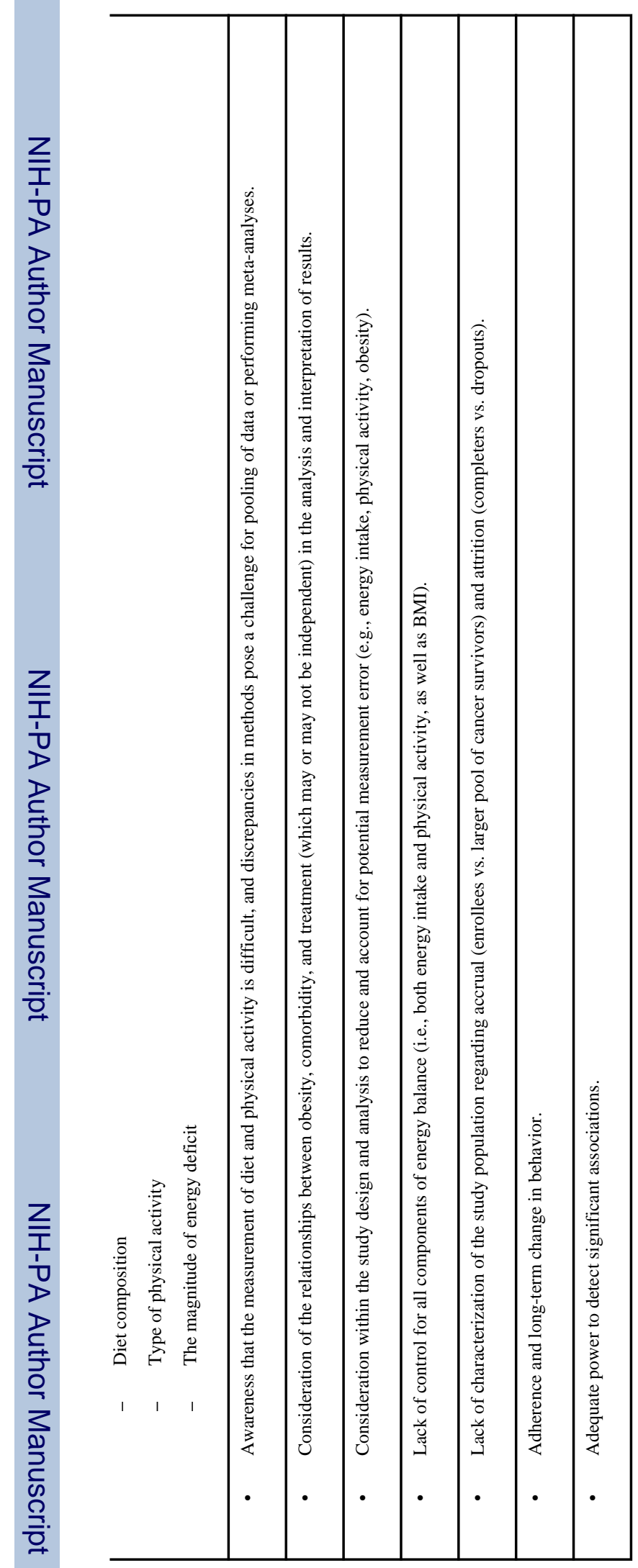

Cancer Epidemiol Biomarkers Prev. Author manuscript; available in PMC 2013 August 01. 


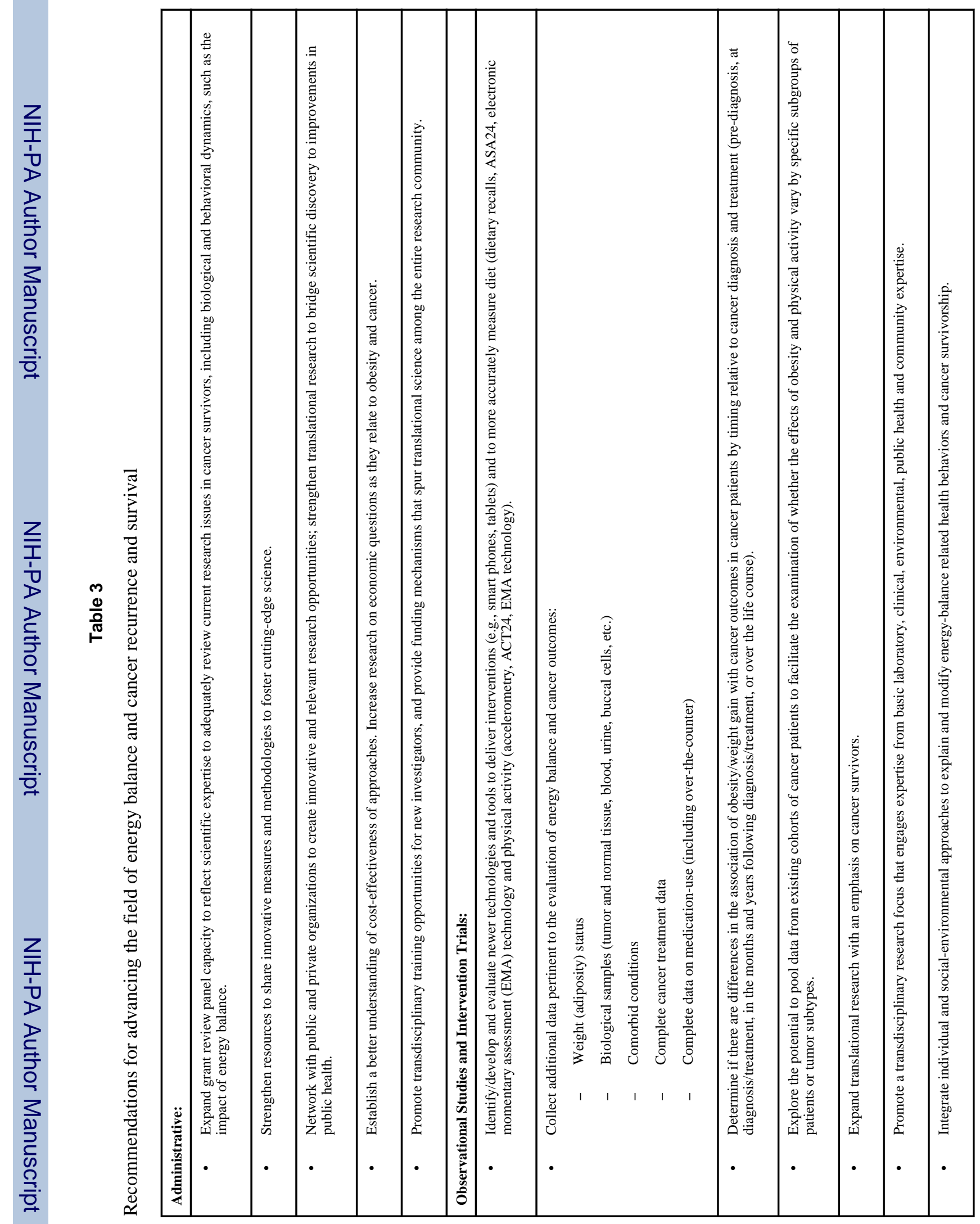

Cancer Epidemiol Biomarkers Prev. Author manuscript; available in PMC 2013 August 01. 


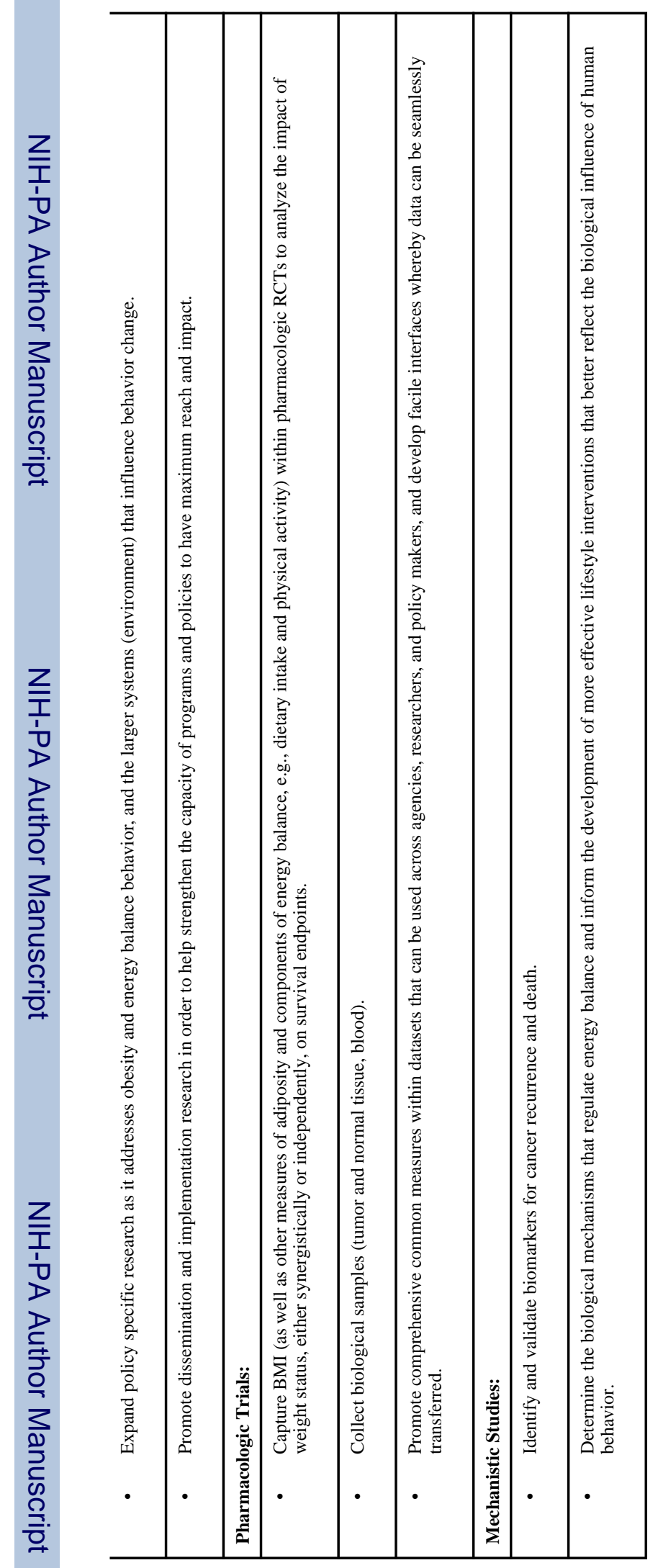

Cancer Epidemiol Biomarkers Prev. Author manuscript; available in PMC 2013 August 01. 